\title{
Influence of season and sex on the inhibitory effect of ovine follicular fluid on plasma gonadotrophins in gonadectomized sheep
}

\author{
J. K. Findlay, T. W. Gill and B. W. Doughton \\ Medical Research Centre, Prince Henry's Hospital, St Kilda Road, Melbourne, Victoria 3004, \\ Australia
}

\begin{abstract}
Summary. The inhibitory effects of follicular fluid on FSH secretion were similar in gonadectomized male and female sheep, and in the anoestrous and breeding seasons. Significant suppression of LH was variable and was observed only at the highest dose of follicular fluid when suppression rarely exceeded $50 \%$ of pretreatment values. Basal plasma FSH and LH concentrations were higher in castrated males than in ovariectomized females in both seasons. Plasma FSH concentrations in gonadectomized males and females and LH concentrations in the males were lower in the anoestrous than the breeding season. Therefore, in the absence of the gonads, sex and photoperiod can influence hypothalamic control of basal pituitary gonadotrophin secretion in males and females, whereas the feedback effect of non-steroidal factors in follicular fluid (inhibin) on FSH secretion is not influenced by photoperiod or sex.
\end{abstract}

\section{Introduction}

Ovine follicular fluid and rete testis fluid are both rich sources of inhibin (Hudson et al., 1979; Tsonis et al., 1983) and will suppress FSH secretion in a dose-dependent manner in ovariectomized ewes (Cummins, O'Shea, Bindon, Lee \& Findlay, 1983) and castrated rams (Hudson et al., 1979; Blanc, Hochereau-de Reviers, Cahoreau, Courot \& Dacheux, 1981). The negative feedback effect of steroids on gonadotrophin secretion in gonadectomized sheep (Pelletier \& Ortavant, 1975; Legan \& Karsch, 1980) is influenced by photoperiod, but it is not known whether photoperiod influences the degree to which inhibin can suppress the secretion of FSH.

The sex of rats appears to influence the degree to which follicular fluid can suppress FSH secrection, females being more responsive than males at high doses of follicular fluid (de Jong, Welschen, Hermans, Smith \& van der Molen, 1978; Hermans, van Leeuwen, Debets \& de Jong, 1980). However, there were confounding effects of age (Hermans et al., 1980) and the relative response of FSH was not always based on studies in males and females with the same inhibin preparations given by the same route of administration in the same experiment (Eddie et al., 1980; Lorenzen, Dworkin \& Schwartz, 1981; Cummins et al., 1983). In this study, the effects of ovine follicular fluid on peripheral concentrations of plasma FSH and LH were compared in the anoestrous and breeding seasons in gonadectomized male and female sheep matched for age and breed.

Goodman, Bittman, Foster \& Karsch (1982) showed that seasonal changes in the pattern of LH secretion can occur, independent of the presence of steroid feedback, in chronically ovariectomized ewes. Similar studies on castrated male sheep have not been reported. We have therefore also compared pretreatment basal plasma gonadotrophin concentrations in the two sexes during both seasons. 


\section{Materials and Methods}

Sheep and blood sampling. Crossbred Merino ewes and rams (1.5-2 years old) from the same flock were gonadectomized at least 6 weeks before the start of the experiment in the anoestrous season (November). The same animals were tested in the breeding season (April) and again in the following anoestrous season. On the day before blood sampling began (Day 1), the animals were weighed and one jugular vein of each animal was cannulated with Silastic tubing (Dow Corning, MI, U.S.A.) fitted with a three-way tap and kept filled with heparinized saline $(0.9 \mathrm{~g} \mathrm{NaCl} / 1 ; 75 \mathrm{U}$ heparin $/ \mathrm{ml}$ ). Blood samples were collected into heparinized syringes, and the plasma was harvested and stored at $-15^{\circ} \mathrm{C}$. Blood samples were collected hourly for $6 \mathrm{~h}$ beginning at $09: 00 \mathrm{~h}$ on Days 1-4 of the experiment, except in the second anoestrous season, when series of samples were collected on Days 1 and 3 only. Composite plasma samples were formed for each animal on each day and assayed for $\mathrm{LH}$ and $\mathrm{FSH}$.

Six ewes remained intact and were run with vasectomized rams to detect oestrus and confirm the times of the breeding and anoestrous seasons. In both anoestrous periods, none of these ewes exhibited behavioural oestrus from 2 weeks before until 2 weeks after the experiment and all ewes had plasma concentrations of progesterone $<0.5 \mathrm{nmol} / 1$, indicative of anoestrus. In April, all the entire ewes exhibited at least 2 regular oestrous cycles before and during the experiment and were observed to have plasma progesterone concentrations ranging from 3.4 to 8.4 (mean $6.4 \pm 1.7$ s.d.) $\mathrm{nmol} / \mathrm{l}$ in blood samples taken 10 days after oestrus, indicative of ovulation and normal luteal function.

Treatments. Follicular fluid from sheep ovaries collected at the abattoirs without regard for time of year was pooled, treated with dextran-coated charcoal according to the method of Tsonis et al. (1983), and stored at $-15^{\circ} \mathrm{C}$ in volumes sufficient for each time of treatment. This preparation had an oestradiol- $17 \beta$ concentration of $0.22 \mathrm{pmol} / 1$ by radioimmunoassay (see below) and an inhibin potency of $20.5 \mathrm{kU} / \mathrm{ml}(19 \cdot 1-22.0,95 \%$ confidence intervals; index of precision of the bioassay, $\lambda=$ 0.09), measured at 3 dilutions in the in-vitro pituitary cell bioassay for inhibin (Scott, Burger \& Quigg, 1980) with modifications described by Lee, Quigg, McMaster, Burger \& Leversha (1983). Briefly, these modifications involved measuring FSH in the culture medium of pituitary cells prepared from immature females rather than in the pituitary cells of mature male rats. The potencies of a number of follicular fluid samples relative to the inhibin standard from ovine testicular lymph protein (1 U/mg) (Eddie, Baker, Higginson \& Hudson, 1979) were similar in the two bioassays (C. G. Tsonis \& V. W. K. Lee, unpublished observations).

Treated animals (2-4/group) received about $0.5,1.0$ or $2.0 \mathrm{ml}$ follicular fluid, the final volume being adjusted to give a similar dose of inhibin activity ( $\mathrm{U} / \mathrm{kg}$ live weight) within treatment groups on each occasion. Injections were given s.c. at $08: 30$ and 17:00 h on each of Days 2 and 3 of the experiment, similar to the treatment regimen described by Cummins et al. (1983).

Control animals (4/group) received s.c. injections of $2 \mathrm{ml}$ serum, treated with dextran-coated charcoal as described above, from an hypophysectomized ewe. This preparation had no detectable levels of inhibin $(<0.004 \mathrm{kU} / \mathrm{ml})$ or oestradiol- $17 \beta(<0.05 \mathrm{pmol} / \mathrm{l})$.

Hormone assays. The data for hormone assays were computed by the method of Burger, Lee \& Rennie (1972).

Plasma concentrations of FSH and LH were determined by radioimmunoassays (Lee $e t$ al., 1976; Bremner, Findlay, Lee, de Kretser \& Cumming, 1980) using NIAMDD-oFSH-13 (biological potency $15 \times \mathrm{NIH}-\mathrm{FSH}-\mathrm{S}$ 1) and NIH-LH-S18 as standards, respectively. All of the samples were assayed within one assay, and were read on that portion of the standard curve where the withinassay coefficient of variation (CV) was $<15 \%$ over the range $5-312 \mathrm{ng} \mathrm{FSH} / \mathrm{ml}$ (minimum $6.7 \%$ ) and $1 \cdot 2-61 \cdot 3 \mathrm{ng} \mathrm{LH} / \mathrm{ml}$ (minimum $5 \cdot 1 \%$ ). The respective sensitivities of the FSH and LH assays were 1.2 and $0.44 \mathrm{ng} / \mathrm{ml}$.

Oestradiol-17 and progesterone concentrations in follicular fluid, serum or plasma were 
measured in solvent extracts by radioimmunoassay using WHO matched reagents (Carson, Trounson \& Findlay, 1982). Recovery was $>90 \%$ and no corrections were made for losses. The sensitivities of the oestradiol-17 $\beta$ and progesterone assays were 25.0 and $15.0 \mathrm{fmol} / \mathrm{tube}$, respectively and the within-assay CVs were 4.5 and $7.1 \%$, respectively.

Analysis of data. Mean plasma FSH concentrations in males and females on Day 1 did not differ between anoestrous seasons 1 and 2 ( $t$ test; $P>0.05$ ), therefore the anoestrous data were pooled within sexes. The effects of season and sex on pretreatment (Day 1) plasma gonadotrophin concentrations were analysed by Student's paired and unpaired $t$ tests (Table 1). The gonadotrophin concentrations on Days 2, 3 and 4 were expressed as percentages of the concentrations on Day 1 for each ewe to reduce between-animal variation. These percentages were subjected to (a) analysis of variance for repeated measurements and trend analysis to determine the degree to which the data within treatment groups conformed with a linear trend up or down (Winer, 1971) and (b) analysis of variance and Duncan's multiple range F-test to determine the effects of dose of follicular fluid within days. The effects of sex and season on the response of FSH to ovine follicular fluid in gonadectomized sheep were analysed by comparing, on Day 3, the percentage suppression of FSH at the highest dose of follicular fluid. Day 3 was chosen because it was the period of observation when the suppression of FSH was maximal or approaching the maximum. By Day 4, FSH concentrations in some groups were increasing (Text-fig. 1; Cummins et al., 1983).

\section{Results}

\section{Basal gonadotrophin concentrations}

The concentrations of FSH and LH on Day 1 were significantly higher in castrated males than ovariectomized females in the anoestrous $(P<0.005)$ and breeding seasons $(P<0.01)$ (Table 1$)$. In the castrated males, the concentrations of FSH $(P<0.05)$ and LH $(P<0.005)$ were significantly lower in the anoestrous seasons than in the breeding season. Similarly, the concentrations of FSH were lower in ovariectomized females in the anoestrous seasons than the breeding season $(P<$ $0 \cdot 05$ ), but the mean concentrations of LH did not differ significantly between seasons (Table 1).

Table 1. Peripheral concentrations $(\mathrm{ng} / \mathrm{ml})$ of LH and FSH in plasma of gonadectomized male and female sheep in the anoestrous and breeding seasons

\begin{tabular}{llccc}
\hline Hormone & Sex & Anoestrous season 1 & Breeding season & Anoestrous season 2 \\
\hline FSH & Male & $123 \pm 9(16)$ & $179 \pm 17(16)^{*}$ & $95 \pm 8(16)$ \\
& Female & $91 \pm 14(10) \dagger$ & $111 \pm 14(10)^{*} \ddagger$ & $72 \pm 8(13) \dagger$ \\
LH & Male & $14 \cdot 7 \pm 1 \cdot 2(16)$ & $16.9 \pm 1 \cdot 3(16)^{* *}$ & - \\
& Female & $10.9 \pm 1.5(11) \dagger$ & $12.0 \pm 1 \cdot 0(11) \ddagger$ & - \\
\hline
\end{tabular}

Values are mean \pm s.e.m. for the no. of ewes indicated in parentheses.

$* P<0.05,{ }^{* *} P<0.005$ versus anoestrous season value, independent $t$ test for FSH; paired $t$ test for LH.

$\ddagger P<0.005, \ddagger P<0.01$, versus male value, independent $t$ test.

\section{Treatment with ovine follicular fluid and hypophysectomized ewe serum}

Treatment with control serum was not associated with a significant linear trend up or down in plasma LH (Table 2) or FSH (Text-fig. 1) concentrations in any group $\left(F_{3,12}>3.49\right.$ for males; $F_{3,8}$ $>4.07$ for females; $P<0.05$ ).

Treatment with follicular fluid had a significant suppression on plasma FSH concentrations in all groups particularly at the highest dose on Day $3(P<0.05)$ and Day $4(P<0.05$; except males on Day 4 in the first anoestrous season, $P>0.05)$, but not on Day $2(P>0.05)$ (Text-fig. 1). Maximum suppression of FSH was observed on Days 3 or 4, with a tendency for concentrations to 
(a) Females

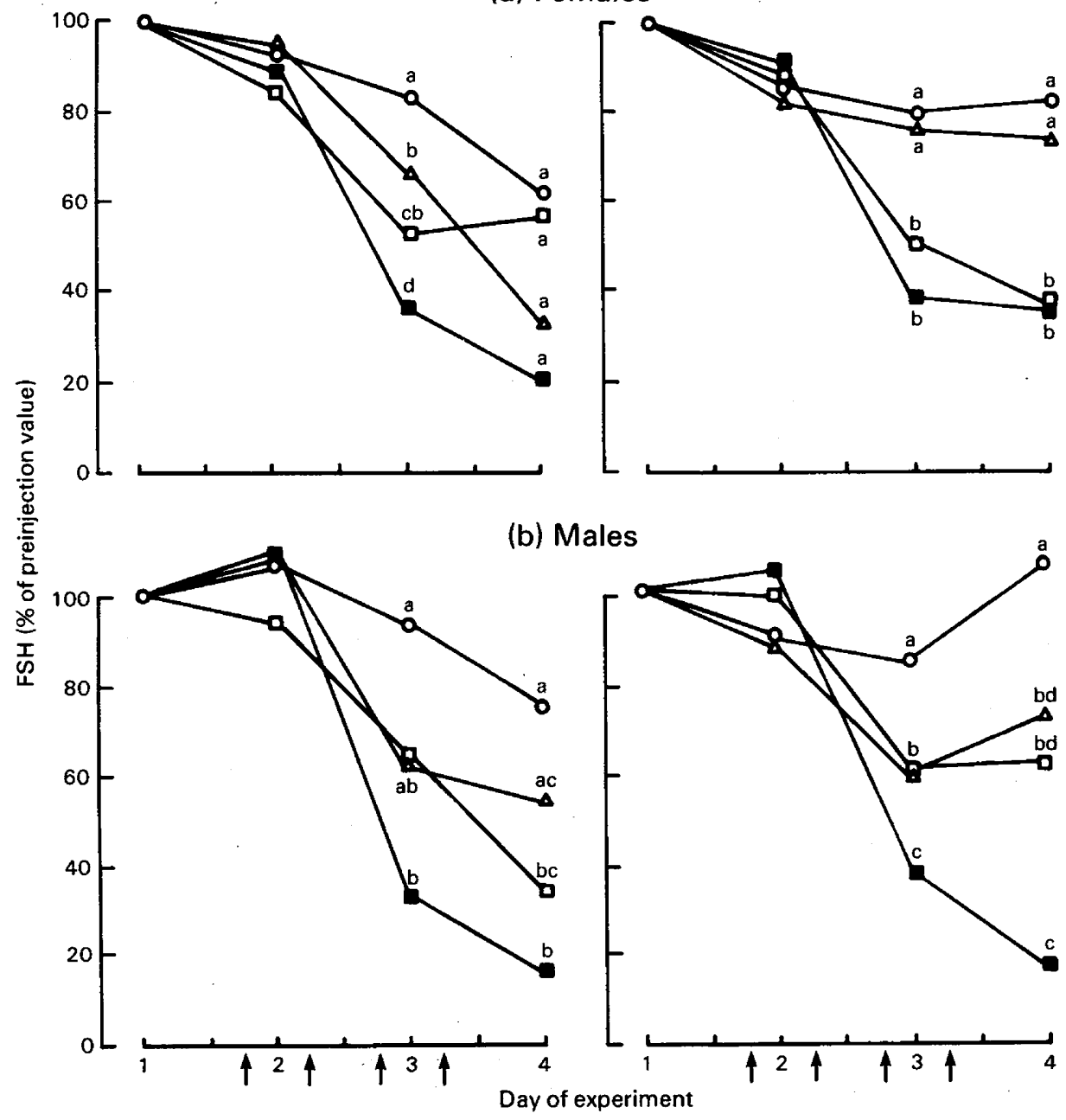

Text-fig. 1. The effects of charcoal-treated serum from an hypophysectomized ewe and various doses of charcoal-treated ovine follicular fluid on plasma FSH concentrations $(\%$ of values on Day 1 before treatment) in gonadectomized (a) female and (b) male sheep in the breeding season and anoestrous season 1. Injections (arrows) were given s.c. as $0.5(\triangle), 1.0(\square)$ or $2.0 \mathrm{ml}$ (D) follicular fluid or $2.0 \mathrm{ml}(O)$ serum. ${ }^{a-d}$ Values within days with different superscripts differ significantly, $P<0.05$.

be increasing by Day 4 in animals treated with lower doses of follicular fluid. Significant suppression of LH was observed only at the highest dose of follicular fluid (Table 2), but the response was variable and the suppression of $\mathrm{LH}$ rarely exceeded $50 \%$ of pretreatment values, whereas FSH fell to around $30-40 \%$ of pretreatment values (Text-fig. 1).

Suppression of FSH (mean \pm s.e.m. \% values on Day 1 ) on Day 3 after the highest dose of follicular fluid was as follows: anoestrus 1 ; males, $36 \pm 8$; females, $33 \pm 5$ : breeding season; males, $39 \pm 2$; females, $34 \pm 4$, and did not differ significantly $(P>0.05$, dependent and independent $t$ test). 
Table 2. Mean LH (\% of concentrations on Day 1) \pm s.d. on Days 2-4 after treatment of gonadectomized male and female sheep with serum (Control) or the highest dose $(2 \mathrm{ml})$ of ovine follicular fluid (oFF)

\begin{tabular}{llccc}
\hline \multicolumn{1}{c}{ Season } & \multicolumn{1}{c}{ Treatment } & Day 2 & Day 3 & Day 4 \\
\hline Males & & & & \\
Anoestrus 1 & Serum & $113 \pm 32$ & $86 \pm 12^{\mathrm{a}}$ & $109 \pm 49$ \\
Breeding Season & oFF & $115 \pm 41$ & $63 \pm 8^{\mathrm{a}}$ & $54 \pm 18$ \\
& Serum & $94 \pm 11$ & $94 \pm 3^{\mathrm{b}}$ & $86 \pm 10$ \\
& oFF & $91 \pm 5$ & $67 \pm 10^{\mathrm{b}}$ & $69 \pm 7$ \\
\hline Females & & & & \\
Anoestrus 1 & Serum & $95 \pm 4$ & $63 \pm 5$ & $82 \pm 18$ \\
Breeding Season & oFF & $97 \pm 55$ & $44 \pm 17$ & $41 \pm 19$ \\
& Serum & $83 \pm 10$ & $95 \pm 14$ & $92 \pm 7^{\mathrm{c}}$ \\
& oFF & $91 \pm 19$ & $74 \pm 19$ & $68 \pm 9^{\mathrm{c}}$ \\
\hline
\end{tabular}

a. b.c Means with same superscript differ significantly, $P<0.05$. There were no significant differences $(P>0 \cdot 05)$ in LH between control animals and animals treated with 0.5 and $1.0 \mathrm{ml}$ oFF/injection (Duncan's Multiple Range F-test).

\section{Discussion}

This study shows that the response of FSH to ovine follicular fluid in adult gonadectomized animals was not influenced by the sex of the sheep or the season (photoperiod). It confirms the effects of treatment with preparations rich in inhibin activity on plasma FSH concentrations and, at the highest doses, on LH concentrations in gonadectomized sheep (Hudson et al., 1979; Blanc et al., 1981; Cummins et al., 1983).

The study shows that the changes in FSH responses with time were similar in gonadectomized male and female sheep when follicular fluid was given by s.c. injection, and confirm an earlier observation for ewes by Cummins et al. (1983). This time course of suppression is very likely to be influenced by the route of administration of follicular fluid. Tsonis (1984) has shown that maximum suppression of FSH occurs within $12 \mathrm{~h}$ when ovine follicular fluid is given as a single i.v. injection to ovariectomized ewes.

Two studies of rats indicated that the relative responses of FSH to bovine and porcine follicular fluid, respectively, were greater in gonadectomized females than males, particularly at high doses (Hermans et al., 1980; Lorenzen et al., 1981). However, the response depended on the age of the rats and the time after surgery (up to $72 \mathrm{~h}$ ). When dose-dependent decreases in plasma FSH concentrations were observed $8 \mathrm{~h}$ after injection of bovine follicular fluid into male and female rats gonadectomized $48 \mathrm{~h}$ earlier, the relative responses appeared to be similar, except at the highest dose when FSH suppression appeared greater in females (de Jong et al., 1978). In this study no statistical difference was observed in the ability of ovine follicular fluid to inhibit FSH in gonadectomized male and female sheep.

The absence of a change with season in the relative FSH response to follicular fluid in both sexes suggests that inhibin is not involved in the seasonal regulation of gonadal function. Therefore, the lower concentrations of FSH in intact ewes (Findlay \& Cumming, 1976) and rams (Lincoln \& Short, 1980) in the anoestrous compared with the breeding season are likely to be due to enhanced responsiveness to oestradiol-17 $\beta$ (Legan \& Karsch, 1980) and testosterone (Pelletier \& Ortavant, 1975), respectively, and to steroid-independent decreases in the hypothalamic stimulation of pituitary function (Goodman et al., 1982; this study). It is possible that the relative response of plasma FSH to follicular fluid is enhanced in the presence of steroids, particularly in the anoestrous season. There is evidence of synergistic actions of inhibin and oestradiol-17 $\beta$ or testosterone in the control of FSH secretion in gonadectomized rodents (Bronson \& Channing, 1978; Hopkinson, Fritze, Chari, Sturm \& Hirschhauser, 1977; Peek \& Watkins, 1980) and mares (Miller, Wesson \& Ginther, 1981), but no such studies in sheep have been reported. 
The higher mean FSH concentrations in gonadectomized sheep in the breeding than in the anoestrous season are consistent with previous reports for intact sheep (Findlay \& Cumming, 1976; Lincoln \& Short, 1980). The pulse amplitude and frequency of LH has been observed to change inversely between seasons in chronically ovariectomized ewes, resulting in similar mean LH concentrations throughout the year (Goodman et al., 1982). We confirmed that mean LH does not change significantly with season in ovariectomized ewes in this study, but in castrated males LH concentrations were higher in the breeding than anoestrous seasons. These effects attributed to season are unlikely to be a function of time after gonadectomy of both sexes, because gonadotrophin concentrations in plasma plateau by 20 days after surgery (Blanc et al., 1981; Wright, Stelmasiak \& Anderson, 1983).

The higher mean LH and FSH concentrations in gonadectomized male than female sheep, independent of season, has not been reported previously. Hermans et al. (1980) showed data indicating a sex difference in FSH but not LH in 35-day-old rats $8 \mathrm{~h}$ after gonadectomy. The reasons for the higher concentrations of gonadotrophins in chronically castrated male sheep are not known. It may reflect greater GnRH pulse frequency and amplitude, greater sensitivity of the pituitary to GnRH stimulation or lower clearance of FSH in the males. The pituitary content of FSH and LH in intact rams is only $10-20 \%$ of that in cyclic ewes (Robertson, Ellis, Foulds, Findlay \& Bindon, 1984).

In conclusion, this study has shown that the feedback effect of non-steroidal factors in follicular fluid, presumably inhibin, on FSH secretion in gonadectomized sheep is not influenced by photoperiod or sex. In contrast, basal pituitary secretion of gonadotrophins in chronically gonadectomized sheep does change with sex and photoperiod, indicating an influence on hypothalamic control of pituitary function which is independent of the gonads.

We thank Carmen Cocks, Helen Quigg and Con Tsonis for help with assays; the Director and staff of the Animal Research Institute, Werribee, for providing sheep and facilities; and NIAMDD and Dr Leo Reichert, Jr for donating hormone assay standards; and Julie Coleman, Diane Hollingsworth and Anne Saunders for help with the manuscript. The project was supported financially by the Australian Meat Research Committee and the National Health and Medical Research Council of Australia.

\section{References}

Blanc, M.R., Hochereau-de Reviers, M.Th., Cahoreau, C., Courot, M. \& Dacheaux, J.L. (1981) Inhibin: effects on gonadotropin secretion and testis function in the ram and rat. In Intragonadal Regulation of Reproduction, pp. 299-326. Eds P. Franchimont \& C. P. Channing. Academic Press, London.

Bremner, W.J., Findlay, J.K., Lee, V.W.K., de Kretser, D.M. \& Cumming, I.A. (1980) Feedback effects of the testis on pituitary responsiveness to LH-RH infusions in the ram. Endocrinology 106, 329-336.

Bronson, F.H. \& Channing, C.P. (1978) Suppression of serum follicle stimulating hormone by follicular fluid in the maximally estrogenized ovariectomized mouse. Endocrinology 103, 1894-1898.

Burger, H.G., Lee, V.W.K. \& Rennie, G.C. (1972) A generalised computer program for the treatment of data from competitive binding assays including radioimmunoassays. J. Lab. Clin. Med. 80, 302-312.

Carson, R.S., Trounson, A.O. \& Findlay, J.K. (1982) Successful fertilisation of human oocytes in vitro: concentration of estradiol-17\%, progesterone and androstenedione in the antral fluid of donor follicles. J. clin. Endocr. Metab. 55, 798-800.
Cummins, L.J., O'Shea, T., Bindon, B.M., Lee, V.W.K. \& Findlay, J.K. (1983) Ovarian inhibin content and sensitivity to inhibin in Booroola and control strain Merino ewes. J. Reprod. Fert. 67, 1-7.

de Jong, F.H., Welschen, R., Hermans, W.P., Smith, S.D. \& van der Molen, H.J. (1978) Effects of testicular and ovarian inhibin-like activity, using in vitro and in vivo systems. Int. J. Androl., Suppl. 2, 125-138.

Eddie, L.W., Baker, H.W.G., Higginson, R.E. \& Hudson, B. (1979) A bioassay for inhibin using pituitary cell cultures. J. Endocr. 81, 49-60.

Eddie, L.W., Baker, H.W.G., Burger, H.G., de Kretser, D.M., Higginson, R.E., Hudson, B., Lee, V.W.K. \& Niall, H.D. (1980) Suppression of FSH secretion in sheep by infusion of inhibin: dose-response relationship. Proc. 6th Int. Congr. Endocr., Melbourne, Abstr. No. 681 .

Findlay, J.K. \& Cumming, I.A. (1976) FSH in the ewe; effects of season, live weight, and plane of nutrition on plasma FSH and ovulation rate. Biol. Reprod. 15, 335-342.

Goodman, R.L., Bittman, E.L., Foster, D.L. \& Karsch, F.J. (1982) Alterations in the control of luteinizing 
hormone pulse frequency underlie the seasonal variation in estradiol negative feedback in the ewe. Biol. Reprod. 27, 580-589.

Hermans, W.P., van Leeuwen, E.C.M., Debets, M.H.M. \& de Jong, F.H. (1980) Involvement of inhibin in the regulation of follicle stimulating hormone concentrations in prepubertal and adult, male and female rats. J. Endocr. 86, 79-92.

Hopkinson, C.R.N., Fritze, E., Chari, S., Sturm, G. \& Hirschhauser, C. (1977) Interaction between testosterone and an inhibin preparation in male rats. IRCS Med. Sci. 5, 83.

Hudson, B., Baker, H.W.G., Eddie, L.W., Higginson, R.E., Burger, H.G., de Kretser, D.M., Dobos, M. \& Lee, V.W.K. (1979) Bioassays for inhibin: a critical review. J. Reprod. Fert., Suppl. 26, 17-29.

Lee, V.W.K., Cumming, I.A., de Kretser, D.M., Findlay, J.K., Hudson, B. \& Keogh, E.J. (1976) Regulation of gonadotrophin secretion in rams from birth to sexual maturity. J. Reprod. Fert. 46, 1-6.

Lee, V.W.K., Quigg, H., McMaster, J., Burger, H.G. \& Leversha, L. (1983) A sensitive and rapid bioassay for inhibin based on inhibition of pituitary gonadotrophin secretion in vitro. Proc. Endocr. Soc. Aust. 26, 32, Abstr.

Legan, S.J. \& Karsch, F.J. (1980) Photoperiodic control of seasonal breeding in ewes: modulation of the negative feedback action of estradiol. Biol. Reprod. 23, 1061-1068.

Lincoln, G. \& Short, R.V. (1980) Seasonal breeding: Nature's contraceptive. Recent Prog. Horm. Res. 36, $1-52$.

Lorenzen, J.R., Dworkin, G.H. \& Schwartz, N.B. (1981) Specific FSH suppression in male rat by porcine follicular fluid. Am. J. Physiol. 240, E209-E215.
Miller, K.F., Wesson, J.A. \& Ginther, O.J. (1981) Interaction of estradiol and a nonsteroidal follicular fluid substance in the regulation of gonadotrophin secretion in the mare. Biol. Reprod. 24, 354-358.

Peek, J.C. \& Watkins, W.B. (1980) Synergism between bovine seminal plasma extract and testosterone propionate in suppressing serum concentrations of gonadotrophins in acutely castrated rats: a role for inhibin. J. Endocr. 349, 349-355.

Pelletier, J. \& Ortavant, J.R. (1975) Photoperiodic control of LH release in the ram. II. Light-androgen interaction. Acta endocr., Copenh. 78, 442-450.

Robertson, D.M., Ellis, S., Foudds, L.M., Findlay, J.K. \& Bindon, B.M. (1984) Pituitary gonadotrophins in Booroola and control Merino sheep. J. Reprod. Fert. 71, 189-197.

Scott, R.S., Burger, H.G. \& Quigg, H. (1980) A simple and rapid in vitro bioassay for inhibin. Endocrinology 107, 1536-1542.

Tsonis, C.G. (1984) Control of oestrogen and inhibin production during growth and atresia of the sheep ovarian follicle. Ph.D. thesis, Monash University.

Tsonis, C.G., Quigg, H., Lee, V.W.K., Leversha, L., Trounson, A.O. \& Findlay, J.K. (1983) Inhibin in individual ovine follicles in relation to diameter and atresia. J. Reprod. Fert. 67, 83-90.

Winer, B.J. (1971) Statistical Principles in Experimental Design, 2nd edn, p. 296. McGraw Hill Kogakusha, Tokyo.

Wright, P.J., Stelmasiak, T. \& Anderson, G.A. (1983) Suppressed release of LH in ovariectomized postpartum ewes. J. Reprod. Fert. 67, 197-202.

Received 9 May 1994 